\title{
EFFECT OF NATURAL AND ORGANIC AMENDMENTS ON SANDY SOIL PROPERTIES AND PRODUCTIVITY OF SESAME
}

\author{
Nahed A. M. E. Aiad, Kh. A. Shaban and Shereen A. H. Saad \\ Soil, Water and Environ. Res. Inst., Agric. Res. Center (ARC), Giza, Egypt
}

Received: Dec. 3, 2017

Accepted: Dec. 26, 2017

\begin{abstract}
Two field experiments were carried out on sandy soil at Experimental Farm of Ismailia Agric. Res Station for two successive summer seasons (2015 and 2016) to study the effect of individual and combined application of compost and tafla on some soil chemical, physical properties, sesame (Sesamum indicum L) productivity and its chemical composition. Both tafla and compost were added individually at rates of 0, 5, 10 and 15 ton fed fr $^{-1}$ in together at rates of 2.5, 5 and 7.5 ton fed $^{-1}$. The studied treatments arranged in the completely randomized design in three replicates. The obtained results indicated a noticeable reduction in soil $\mathrm{pH}$ as a result of treating the soil with tafla and compost at different rates compared to control, increased the soil EC at different rate of tafla, whereas reduction in soil EC in treating of compost or combined with tafla at different rates. The effect is more pronounced in the soil treated with 7.5 ton compost fed $d^{-1}+7.5$ ton tafla fed $d^{-1}$ and compost alone at rate of 15 ton fed ${ }^{-1}$. However, the organic matter (OM) content of the soil was increased with application of compost alone and in combined with tafla at different rates. The highest OM content were recorded with the treatment of 7.5 ton compost fed ${ }^{-1}+7.5$ ton tafla fed ${ }^{-1}$ followed by 15 ton fed ${ }^{-1}$ of compost compared to control. A slight decreases of soil bulk density (BD), an increase in soil total porosity (TP) were found with application of compost and tafla individually and in together at different rates as compared to control. The values of field capacity, wilting point and the content of available water of sandy soil were increased as a result of the evaluated soil amendments at different application rates. In addition, the obtained data indicated that the yield and its components, straw yield, seed yield and weight of 1000 seeds, were significantly increased by the different studied treatments of both compost and tafla. The highest mean values of yield and its components were found with the combined treatments of compost with tafla at a high application rate compared to the control. Also, there was a significant increment in $\mathrm{N}, \mathrm{P}$ and $\mathrm{K}$ contents (\%) of sesame seeds with treatment of 7.5 ton compost fed ${ }^{-1}+7.5$ ton tafla fed $^{-1}$ compared to control.
\end{abstract}

Key words: Compost, Tafla, Sesame and Sandy soil.

\section{INTRODUCTION}

Egypt has an area of about one million square kilometers. The total agricultural land in Egypt amounts to nearly 3.5 million ha accounting for around $3.5 \%$ of the total land area; however, this area is primarily considered to be virgin desert, with a sandy soil texture that is not optimal for crop production. The imbalance between a growing population and available agricultural land has led to a shortage in food supplies; therefore, the implementation of management practices that can increase crop productivity is of great interest in an area where the amount of land available for cultivation is continuously declining as a result of urbanization (Adriansen, 2009). However, the productivity of sandy soils is mostly limited by several agronomic obstacles. Also, sandy soils usually have poor properties including low specific surface area, low water retention, low organic matter content, low fertility and high infiltration rate. These poor physical properties cause insufficient water use, especially in arid and semi-arid regions. 
These adverse factors can be solved by several means such as different natural conditioners (Al-Omran et al., 2004). The low content of clay in sandy soils usually limits humus accumulation, nutrients and water availability as well as buffering capacity, which is a reason the many of these soils become acidified. Croker et al. (2004) illustrated the increase loses of fertilizer-supplied nutrients from upper soil horizon into deeper soil layers led to low crop yields from sandy soils.

Bentonite (tafla) is widely used to improve poor soils in gardening, particularly, in sandy soils where small amounts of bentonite have been shown to increase growth rates and yields of many plants (Abd El-Hady and Eldardiry. (2012) and Ferguson. (2015). Abou-Gabal et al. (1989) found that, the addition of local tafla or shale (43\% silt, $24 \%$ clay and $32 \%$ fine sand dominated by bentonite) to the sandy soil in Egypt improved soil texture and consequently soil-water plant relationships. Hassan and Abdel Wahab (2013) found that, the low salinity levels were achieved by adding a considerable amount of irrigation water at the beginning of planting process and the improvement in the both soil bulk density and soil total porosity status due to the increase in bentonite application rates. Bentonite addition decreased $\mathrm{NH}_{4}$ in leachate to 44 and $49 \%$ less than clay and control treatments, respectively Suphasit et al. (2010)and El-Diwani et al. (2012) indicated that, the contribution of the bentonite in sandy soil improves its physical properties and water retention. Usman et al. (2005) reported that, the primary effect of bentonite is to improve the water holding capacity and moisture content of soil and through this property contribute to the stimulation of biological activity.

Compost is one from of organic matter producer, which can be used to improve the soil physical, chemical and biological properties of salt affected soils and it can be converted as ideal manure with high contents of macro and micronutrients. Compost reduced the bulk density of a sandy loam by increasing the soil carbon and nitrogen contents (Curtis and Claassen, 2009). The organic materials can improve the physical properties of sandy soils such as soil porosity, infiltration rate and soil water retention (Abdel-Nasser. 2005). Also, application of some organic materials as soil conditioners or amendments act as water absorbent materials that can increase the water retention of soil and improve the soil structure (Ahmed, et al., 2015).

Sesame (Sesamum indicum L.) is a crop highly valued for production of high quality oil. It is also grown in many parts of the world for its insecticidal and medicinal properties as well as for its osmetic and ornamental values. Sesame can also be grown as a spice or as green manure. Sesame (Sesamum indicum L.), a member of the Pedaliaceae family, is one of the ancient cultivated plants mainly for its seeds as oil and food sources: oil (44 - $58 \%$ ), protein (18 - $25 \%)$, carbohydrate (13, $5 \%)$ and ash (5\%) (Akbar et al., 2011 and Kanu, 2011). It is an economically important crop widely cultivated in several countries (Ogbonna and Umar - Shaaba, 2011) and also, sesame is the most conventional oilseed crop cultivated for its edible oil in the sub-continent. Sesame is known as the king of oil seeds due to the high oil content (50 $60 \%$ ) of its seed (Toan et al., 2010).

The objective of this study aims to improve sandy soil properties, yield of sesame plants and its component by some amendment application, inorganic (tafla) and organic (compost) and combination of them under sprinkle irrigation water.

\section{MATERIALS AND METHODS}

Two field experiments were carried out in the Experimental Farm of Ismailia, Agriculture Research Station (A.R.C.) during two successive growing seasons of summer, 2015 and 2016, to evaluate the effect of compost as organic amendment and tafla as 
a natural soil amendment at different application rates on some soil physical and chemical properties of sandy soil and sesame (Sesamum indicum L) productivity under sprinkle irrigation system. Before planting surface soil sample $(0-30 \mathrm{~cm})$ was taken from the experimental field, air dried, ground, sieved through a $2 \mathrm{~mm}$ sieve and analyzed for some soil physical and chemical characteristics according to the methods described by Cottenie et al. (1982); Page et al. (1982) and Gee and Bauder (1986). The obtained data were presented in Table (1). Some characteristics of compost were recorded in Table (2).

The studied treatment were described out in a randomized completely design with three replicates. All farming processes were carried out before planting. Also, the compost and tafla treatments were carried out during tillage individually or in combination. The studied treatments may be listed as follows:

1- Control

2- Tafla at rate $\left(5\right.$ ton fed $\left.^{-1}\right)$

3- Tafla at rate $\left(10\right.$ ton $\left.^{-1} \mathrm{f}^{-1}\right)$

4- Tafla at rate (15 ton fed $\left.{ }^{-1}\right)$

5- Compost at rate $\left(5\right.$ ton fed $\left.^{-1}\right)$

6- Compost at rate (10 ton $\left.\mathrm{fed}^{-1}\right)$

7- Compost at rate $\left(15\right.$ ton $\left.\mathrm{fed}^{-1}\right)$

8- 2.5 ton tafla fed ${ }^{-1}$ combined with 2.5 ton compost fed $^{-1}$
9- 5 ton tafla fed ${ }^{-1}$ combined with 5 ton compost fed ${ }^{-1}$

10- 7.5 ton tafla fed ${ }^{-1}$ combined with 7.5 ton compost fed ${ }^{-1}$

Super phosphate $\left(15.5 \% \mathrm{P}_{2} \mathrm{O}_{5}\right)$ was applied at rate of $20 \mathrm{~kg} \mathrm{fed}^{-1}$ during soil preparation. Nitrogen as ammonium sulphate $(20 \% \mathrm{~N})$ was added at rates of 150 $\mathrm{kg} \mathrm{N} \mathrm{fed}^{-1}$ on three equal doses after 15, 30 and 60 days from sowing. Potassium sulphate $\left(48 \% \mathrm{~K}_{2} \mathrm{O}\right)$ was applied at rate 50 $\mathrm{kg} \mathrm{fed}^{-1}$ on two equal doses at sowing and 30 days of planting. The variety of sesame (Sesamum indicum L) obtained from Crop Institute Agriculture Research Center, Giza, Egypt. The plot aria was $3.5 \times 3.0 \mathrm{~m}^{2}$. Sowing was carried out at May 2015 and May 2016. All experimental plots were irrigated by sprinkler systems. At harvesting time (September) 2015 and 2016, the plants of each experimental unit were taken and separated into straw and seeds. Both straw and seeds were air-dried and weighted to calculate the yield and seeds. A $0.5 \mathrm{~g}$ of each oven dried ground seeds sample was digested using $\mathrm{H}_{2} \mathrm{SO}_{4}, \mathrm{HClO}_{4}$ mixture according to the method described by Chapman and Pratt. (1961). The plant content of $\mathrm{N}, \mathrm{P}$, and $\mathrm{K}$ was determined in plant digestion using the methods described by Cottenie et al. (1982) and Page et al. (1982).

Table (1): Physical and chemical properties of the tested sandy soil.

\begin{tabular}{|c|c|c|c|c|c|c|c|c|}
\hline \multicolumn{3}{|c|}{ Particale size distribution } & \multirow[b]{2}{*}{ Soil texture } & \multirow{2}{*}{$\begin{array}{l}\text { BD } \\
\left(\mathrm{g} \mathrm{cm}^{-1}\right)\end{array}$} & \multirow{2}{*}{$\begin{array}{c}\text { OM } \\
(\%)\end{array}$} & \multirow{2}{*}{$\begin{array}{c}\mathrm{CaCC} \\
(\%)\end{array}$} & \multirow{2}{*}{$\begin{array}{c}\mathrm{EC} \\
\mathrm{dSm^{-1 }}\end{array}$} & \multirow{2}{*}{\begin{tabular}{l}
\multicolumn{1}{c}{$\mathrm{pH}$} \\
$(1: 2.5)$ \\
Water sus.
\end{tabular}} \\
\hline $\begin{array}{r}\text { Sand } \\
(\%)\end{array}$ & $\begin{array}{l}\text { Silt } \\
(\%)\end{array}$ & $\begin{array}{r}\text { Clay } \\
(\%)\end{array}$ & & & & & & \\
\hline 87.41 & 7.21 & 5.38 & Sandy & 1.65 & 0.35 & 1.2 & 0.45 & 7.76 \\
\hline \multicolumn{4}{|c|}{ Soluble cations (meq L- } & \multicolumn{5}{|c|}{ Soluble anions (meq L- } \\
\hline $\mathrm{K}^{+}$ & $\mathrm{Na}$ & $\mathrm{Ms}$ & $\mathrm{Ca}^{++}$ & $\mathrm{SO}_{4}^{--}$ & C & & $\mathrm{HCO}_{3}^{-}$ & $\mathrm{CO}_{3}^{--}$ \\
\hline 0.20 & 0.52 & & 2.10 & 2.5 & & 1.5 & 0.5 & ---- \\
\hline
\end{tabular}

Table (2): Some properties of compost used in experiment.

\begin{tabular}{|c|c|c|c|c|c|c|c|}
\hline $\begin{array}{c}\mathrm{OM} \\
\%\end{array}$ & $\begin{array}{c}\mathrm{pH} \\
1: 10\end{array}$ & $\begin{array}{c}\mathrm{EC} \mathrm{dSm}^{-1} \\
1: 10\end{array}$ & $\begin{array}{c}\text { Total C } \\
(\%)\end{array}$ & $\begin{array}{c}\text { Total N } \\
(\%)\end{array}$ & $\begin{array}{c}\mathrm{C} / \mathrm{N} \\
\text { Ratio }\end{array}$ & $\begin{array}{c}\text { Total } \\
\mathrm{P}(\%)\end{array}$ & $\begin{array}{c}\text { Total } \mathrm{K} \\
(\%)\end{array}$ \\
\hline 45.75 & 7.50 & 2.75 & 26.54 & 1.70 & 15.61 & 0.65 & 0.75 \\
\hline
\end{tabular}


Disturbed and undisturbed soil samples were collected from $(0-30) \mathrm{cm}$ soil depth, for each experimental plot before harvest in the two growth seasons. The soil samples were air- dried ground, sieved and analyzed for some chemical characteristics, i.e., soil $\mathrm{pH}$, the content (\%) of organic matter (OM) and EC (dS $\mathrm{m}^{-1}$ ) according to the methods described by Cottenie et al. (1982) and Page et al. (1982). Undisturbed soil samples were used to determine soil physical properties. Particle size distribution was carried out by the pipette method as described by Gee and Bauder (1986) using sodium hexameta- phosphate as a dispersing agent. Soil bulk density (BD) was determined using the undisturbed soil column and total soil porosity (TP) was calculated as percentage from the obtained values of real and bulk densities according to Richards (1954). Wilting point (WP) was determined according to Stakman and Vanderhast (1962), field capacity (FC) as described by Richards (1954) and available water (AW) was calculated. The obtained of yield and its components and seed content of N, P and $\mathrm{K}$ were statistically analysis using the SPSS program and L.S.D. test at the probability levels of $0.5 \%$ was calculated according to Snedecor and Cochran (1980).

\section{RESULTS AND DISCUSSION Soil chemical properties:-}

Data presented in Table (3) appeared that, application of tafla at the different rates increased the soil EC. The highest values of soil $\mathrm{EC}$ were recorded at the rate 15 ton fed ${ }^{-1}$ of tafla treatment. Therefore, the EC of the soil increased with increasing of clay in the soils, clay greatly this may be due to their exchangeable cations and the water film associated with them and tafla application (McNeil 1980) and (Mustafa 2009). Another reason for increasing soil EC compared to control was due to their high water content by treated by tafla. This resulted also in agreement with the finding of Hartsock et al. (2000) who observed that, positive relationship between soil water and EC was stronger and linear up to $45 \%$ volumetric water content. On the other hand, application of compost decreased the soil EC at the different rates, the lowest values of soil EC were recorded at the treatment 7.5 ton compost fed ${ }^{-1}+7.5$ ton tafla fed $^{-1}$.

Soil $\mathrm{pH}$ may be one the most important parameters pinpointing the overall changes in soil chemical properties, value of $\mathrm{pH}$ was reduced by application of soil amendment under study. Response to compost addition was more pronounced than to tafla one, $\mathrm{pH}$ values decreased in all treatment at different rate. In this respect, Wahab et al. (2010) obtained on similar results. The obtained results manifested that, the evaluated soil amendment play an important role in reduction of soil $\mathrm{pH}$ of the studied soil compared to control. This may be attributed to decomposition of organic materials and the production of organic acids and lor increased partial pressure of $\mathrm{CO}_{2}$ in the soil at mesosphere due to increased microbiological activity leading to decrease the soil EC and $\mathrm{pH}$. These results are similar to that found by Ahmed et al. (2015) and El-Maaz et al. (2014). Organic matter is regarded as the ultimate source of nutrients and microbial activity in the soil. It is the deciding factor in soil structure, water holding capacity, infiltration rate, aeration and porosity of the soil. The presented data in Table (3) showed that, organic matter content (\%) of soil was increased with application of compost alone and in combination with tafla, where the higher content was associated the treatments (15 ton compost fed $^{-1}$ ) and 7.5 ton compost fed ${ }^{-1}+7.5$ ton tafla fed ${ }^{-1}$ compared to control. Generally the obtained results showed that, the combined application of compost and tafla 
Table (3): Effect of tafla and compost application on some chemical properties of the tested soil (mean of two seasons)

\begin{tabular}{|c|c|c|c|}
\hline Treatments & $\begin{array}{c}\mathrm{pH} \\
(1: 2.5)\end{array}$ & $\begin{array}{c}E C \\
\left(d S m^{-1}\right)\end{array}$ & $\begin{array}{l}\text { O.M } \\
(\%)\end{array}$ \\
\hline Control & 7.76 & 0.44 & 0.36 \\
\hline Tafla $\left(5\right.$ ton fed $\left.{ }^{-1}\right)$ & 7.73 & 0.46 & 0.39 \\
\hline Tafla $\left(10\right.$ ton fed $\left.{ }^{-1}\right)$ & 7.69 & 0.50 & 0.44 \\
\hline Tafla $\left(15\right.$ ton fed $\left.{ }^{-1}\right)$ & 7.65 & 0.53 & 0.50 \\
\hline Mean & --- & 0.49 & 0.44 \\
\hline Compost $\left(5\right.$ ton fed $\left.^{-1}\right)$ & 7.70 & 0.42 & 0.43 \\
\hline Compost $\left(10\right.$ ton fed $\left.^{-1}\right)$ & 7.66 & 0.39 & 0.47 \\
\hline Compost(15 ton fed $\left.{ }^{-1}\right)$ & 7.62 & 0.36 & 0.54 \\
\hline Mean & --- & 0.39 & 0.48 \\
\hline Tafla $\left(2.5\right.$ ton fed $\left.{ }^{-1}\right)+$ compost $\left(2.5\right.$ ton fed $\left.^{-1}\right)$ & 7.65 & 0.40 & 0.47 \\
\hline Tafla $\left(5\right.$ ton fed $\left.{ }^{-1}\right)+$ compost $\left(5\right.$ ton fed $\left.{ }^{-1}\right)$ & 7.62 & 0.37 & 0.54 \\
\hline Tafla $\left(7.5\right.$ ton fed $\left.^{-1}\right)+$ compost $\left(7.5\right.$ ton fed $\left.^{-1}\right)$ & 7.57 & 0.35 & 0.57 \\
\hline Mean & --- & 0.37 & 0.53 \\
\hline
\end{tabular}

led to increase of mean values of OM (\%) compared with other treatments. On the other hand the percentage of OM was positively influenced with both amendments. This may be due to higher OM content of those amendment consequently, augmented the OM content of soil received these material. These results are in agreement in the findings of Emmanuel et al. (2012); Hassan and Mahmoud (2013) and Ahmed et al. (2015). Aiad, (2010) found that, the application of compost significantly increased both OM and CEC compared to control. Generally, the different chemical sandy soil properties were more affected by the amendment addition compared to the control .

\section{Physical properties:}

Bulk density, total soil porosity and Soil moisture parameters

Both bulk density (BD) and total soil porosity (TP) are closely related and linearly inversely correlated and decreased bulk density is a direct function of increased total porosity (Black et al., 1965). Data in Table (4) revealed that, the values of soil bulk density were decreased with different treatments under study; the low values of compost were than those found with tafla or control treatment. These decreases may be resulted from soil aeration due to increases in soil porosity with the structural stability. On the other hand, data showed that, values of total soil porosity tended to increase with application of the studied amendment compared to control. Application treatment 7.5 ton tafla fed ${ }^{-1}+7.5$ ton compost fed ${ }^{-1}$ gave the lowest decrease of soil bulk density followed by application of compost treatment at the rate 15 ton fed $^{-1}$. Table (4) showed that the highest value of total soil porosity was found in the soil treated with combined of 7.5 ton compost fed ${ }^{-1}+7.5$ ton tafla fed ${ }^{-1}$. The effect of compost and tafla on total porosity was increase, as well as, the different rate of the evaluated soil amendments was increased of total soil porosity. These results can be attributed to 
Nahed A. M. E. Aiad, et al.,

the redistribution of soil particles, the increase in bulk soil volume and the binding action of tafla which assess to improve soil structure, mainly in aggregate formation. These findings are very close to that obtained by Omran et al. (2002). These results agree with those reported by Usman et al. (2005) and Eldardiry et al. (2015). ElKholy et al. (2000) indicated that application of compost increase of total porosity compared with control. Hassan and Abdel Wahab (2013) reported that the bentonite conditioner application rates due to increase of total porosity status in sandy soil. Consequently, porosity as an index of the relative volume of soil pores should be improved due to the beneficial effect of organic amendment in improving soil aggregates. These results are in consonance with the findings of ElMaghraby et al, (2011). Ahmed et al. (2015) stated that, the application of compost and bentonite conditioners led to the reduction of soil bulk density as well as increase in soil total porosity. The obtained data also showed that, values of soil field capacity (FC), wilting point (WP) and the calculated available water (AW) are considered to be the three main soil moisture constants were obviously responded to applied treatments. Data appeared that applications of compost, tafla and their combined at all rates was favorable for FC\%, WP\% and AW\% compared to the control. Application treatment 7.5 ton tafla fed ${ }^{-1}+7.5$ ton compost fed ${ }^{-1}$ gave the highest soil moisture constants followed by application of compost treatment at the rate 15 ton fed $^{-1}$. These increases attributed to high specific surface area and water holding capacity of the used soil amendments. Consequently, increase in soil moisture retention parameters is considered as the greatest goal in the reclamation of sandy soils, where water deficit occurred. These may be rendered to the increase in fine particles content (clay fraction) resulted from tafla additives which act as water moderators, and which will adsorb up to $55 \%$ of its weight in water. The highly magnitude of these results is saving a lot of irrigation water which can be used to reclaim, cultivate new areas and to enhance water use efficiency of most crops. These results are in consonance with the findings of Usman et al. (2005) and Hassan and Abdel Wahab (2013).

Table (4): Bulk density $\left(\mathrm{g} \mathrm{cm}^{-3}\right)$, soil total porosity (\%), and soil moisture constants (\%) of the tested sandy soil (mean of two seasons)

\begin{tabular}{|c|c|c|c|c|c|}
\hline \multirow{2}{*}{ Treatments } & \multirow{2}{*}{\begin{tabular}{|c|}
$\mathrm{BD}$ \\
$\left(\mathrm{g} / \mathrm{cm}^{3}\right)$
\end{tabular}} & \multirow{2}{*}{$\begin{array}{l}\text { T.P. } \\
(\%)\end{array}$} & \multicolumn{3}{|c|}{ Soil moisture constants (\%) } \\
\hline & & & F.C. & W.P. & A.W. \\
\hline Control & 1.64 & 38.11 & 13.20 & 6.10 & 7.10 \\
\hline Tafla (5 ton fed $\left.{ }^{-1}\right)$ & 1.62 & 38.87 & 13.58 & 6.20 & 7.38 \\
\hline Tafla $\left(10\right.$ ton fed $\left.^{-1}\right)$ & 1.59 & 40.00 & 14.05 & 6.35 & 7.70 \\
\hline Tafla $\left(15\right.$ ton fed $\left.^{-1}\right)$ & 1.55 & 41.51 & 14.47 & 6.49 & 7.98 \\
\hline Mean & 1.58 & 40.12 & 14.03 & 6.34 & 7.68 \\
\hline Compost $\left(5\right.$ ton fed $\left.^{-1}\right)$ & 1.59 & 40.00 & 13.80 & 6.31 & 7.49 \\
\hline Compost $\left(10\right.$ ton fed $\left.^{-1}\right)$ & 1.56 & 41.13 & 14.55 & 6.45 & 8.10 \\
\hline Compost(15 ton fed $\left.{ }^{-1}\right)$ & 1.53 & 42.26 & 15.20 & 6.70 & 8.50 \\
\hline Mean & 1.56 & 41.13 & 14.51 & 6.48 & 8.03 \\
\hline Tafla $\left(2.5\right.$ ton fed $\left.{ }^{-1}\right)+\operatorname{compost}\left(2.5\right.$ ton fed $\left.^{-1}\right)$ & 1.57 & 40.75 & 14.50 & 6.40 & 8.10 \\
\hline 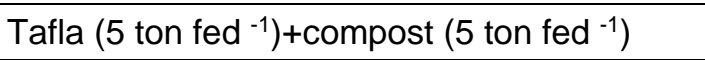 & 1.54 & 41.88 & 15.40 & 6.80 & 8.60 \\
\hline Tafla $\left(7.5\right.$ ton fed $\left.^{-1}\right)+$ compost $\left(7.5\right.$ ton fed $\left.^{-1}\right)$ & 1.50 & 43.39 & 16.01 & 6.98 & 9.03 \\
\hline Mean & 1.53 & 42.00 & 15.30 & 6.72 & 8.57 \\
\hline
\end{tabular}


Effect of tafla and compost on yield and yield component of sesame plants:

The beneficial results obtained from soil properties and amendments status logically, reflected on plants growth and consequently their yield of seeds and straw. Sesame yield (seeds and straw) as influenced by various treatments, results in Table (5) show the effect of individual and combined application of compost and tafla on sesame productivity under sandy soil condition. These data showed that, the straw yield, seed yield and weight of 1000 seeds were significantly increased by the different studied treatments. The highest mean values of straw yield, seed yield and weight of 1000 seeds were found in the plants grown in the soil treated with 7.5 ton tafla fed $^{-1}+7.5$ ton compost fed ${ }^{-1}$. The relative increase of mean values for straw yield, seed yield and weight of 1000 seeds were $16.4,14.22$ and $6.20 \%$ respectively as affected by tafla treatment , 21.6, 19.77 and $11.38 \%$ respectively as affected by compost added and $26.13,26.22$ and $14.83 \%$ respectively, as affected by combined application of compost combined with tafla rates application compared with control. These results are in agreement with these obtained by Nadeem et al. (2015). Shaban et al. (2012) found that the application of compost was increase values of yield and its components, the highest increases were obtained by using compost in combination with $40 \mathrm{~kg} \mathrm{~N}$ fed $^{-1}$. El etr et al. (2016) found that the compost application was significant effect on dry weight of sesame. The increase of dry weight was caused by improvement of soil quality and increase organic matter content.

Table (5): Effect of tafla and compost on some growth parameters of sesame plant in tested sandy soil (mean of two seasons)

\begin{tabular}{|c|c|c|c|}
\hline Treatments & $\begin{array}{c}\text { Straw yield } \\
\text { kg fed } \text { fed }^{-1}\end{array}$ & $\begin{array}{l}\text { Seeds yield } \\
\text { kg fed }{ }^{-1}\end{array}$ & $\begin{array}{c}\text { Weight of } \\
1000 \text { seeds } \\
\text { (g) }\end{array}$ \\
\hline Control & 750 & 450 & 2.90 \\
\hline Tafla (5 ton fed ${ }^{-1}$ ) & 780 & 465 & 2.94 \\
\hline Tafla $\left(10\right.$ ton fed $\left.^{-1}\right)$ & 884 & 512 & 3.00 \\
\hline Tafla (15 ton fed ${ }^{-1}$ ) & 955 & 565 & 3.30 \\
\hline Mean & 873 & 514 & 3.08 \\
\hline Compost (5 ton fed ${ }^{-1}$ ) & 822 & 480 & 3.05 \\
\hline Compost (10 ton fed $\left.{ }^{-1}\right)$ & 930 & 535 & 3.25 \\
\hline Compost(15 ton fed $\left.{ }^{-1}\right)$ & 984 & 602 & 3.40 \\
\hline Mean & 912 & 539 & 3.23 \\
\hline Tafla (2.5 ton fed $\left.\left.{ }^{-1}\right)+{\text { compost }(2.5 \text { ton } \text { fed }}^{-1}\right)$ & 890 & 490 & 3.20 \\
\hline Tafla (5 ton fed $\left.{ }^{-1}\right)+$ compost $\left(5\right.$ ton fed $\left.^{-1}\right)$ & 955 & 574 & 3.35 \\
\hline Tafla $\left(7.5\right.$ ton fed $\left.{ }^{-1}\right)+$ compost $\left(7.5\right.$ ton fed $\left.^{-1}\right)$ & 995 & 640 & 3.45 \\
\hline Mean & 946 & 568 & 3.33 \\
\hline LSD $0.05 \%$ & ** 9.13 & ** 10.52 & ** 0.09 \\
\hline
\end{tabular}


Hassan and Abdel Wahab. (2013) indicated that, the weight of 100 seeds $(\mathrm{g})$ and the seeds yield were significantly increased by increasing the bentonite conditioner rates. The modification that occurred in soil chemical and hydro-physical properties by bentonite as conditioner for El-Salhia sandy soils caused an increase in their productivity. These results are similar to that found by Abdel-Nasser et al. (2007). Ahmed et al. (2015) mentioned that, the yield and its components, (weight of 100 seeds, yield of straw (ton fed ${ }^{-1}$ ) yield of seeds (ton fed ${ }^{-1}$ ), were significantly increased by the different studied treatments of both compost and bontonite. The highest mean values of yield and its components were the combined treatments of bentonite and with compost at a high application rate compared to the control treatment. Abd ElHady and Eldardiry (2012) and Abd ElRheem et al. (2016) obtained an similar results.

\section{Macronutrient concentrations (\%) in sesame seed}

The entire treatments positively influenced nitrogen, phosphorus and potassium concentrations, in sesame seeds.
Data presented in Table (6) showed that the $\mathrm{N}, \mathrm{P}$ and $\mathrm{K}$ concentrations (\%) in seeds of sesame increased with all treatments compared to control. The highest values of $\mathrm{N}, \mathrm{P}$ and $\mathrm{K}$ in seeds were obtained for soil application with tafla combined compost at the high rates. All combinations between either organic or inorganic amendment at different rates affected on $\mathrm{N}, \mathrm{P}$ and $\mathrm{K}$ concentrations in sesame seeds. The relative increase of mean values for $N, P$ and $\mathrm{K}$ concentrations in sesame seeds were $29.74,13.16$ and $9.09 \%$ respectively as affected by tafla treatment , $37.5,26.31$ and $16.66 \%$ respectively as affected by compost added and $40.95,36.84$ and $22.73 \%$ respectively, as affected by combined application of compost combined with tafla rates application compared with control. These results are in agreement with Antoun et al. (2010). Generally the obtained increases in macronutrient concentrations in seeds may be due to the availability of them in the soil as a result of decreasing soil $\mathrm{pH}$ and EC caused by the action of compost or tafla These results agreed with those obtained by Shaban et al. (2012), Ahmed et al. (2015) and El -Etr et al. (2016).

Table (6): Macronutrients in the seeds of sesame plant

\begin{tabular}{|c|c|c|c|}
\hline \multirow{2}{*}{ Treatments } & \multicolumn{3}{|c|}{ Macronutrients \% } \\
\hline & $\mathrm{N}$ & $P$ & $\mathrm{~K}$ \\
\hline Control & 2.32 & 0.38 & 0.66 \\
\hline 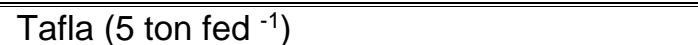 & 2.79 & 0.40 & 0.68 \\
\hline Tafla $\left(10\right.$ ton fed $\left.^{-1}\right)$ & 3.00 & 0.43 & 0.72 \\
\hline Tafla (15 ton fed ${ }^{-1}$ ) & 3.25 & 0.47 & 0.76 \\
\hline Mean & 3.01 & 0.43 & 0.72 \\
\hline Compost $\left(5\right.$ ton fed $\left.^{-1}\right)$ & 3.10 & 0.45 & 0.70 \\
\hline Compost $\left(10\right.$ ton fed $\left.^{-1}\right)$ & 3.16 & 0.49 & 0.79 \\
\hline Compost(15 ton fed $\left.{ }^{-1}\right)$ & 3.32 & 0.52 & 0.83 \\
\hline Mean & 3.19 & 0.48 & 0.77 \\
\hline Tafla $\left(2.5\right.$ ton fed $\left.{ }^{-1}\right)+$ compost $\left(2.5\right.$ ton fed $\left.^{-1}\right)$ & $\overline{3.18}$ & $\overline{0.47}$ & 0.76 \\
\hline 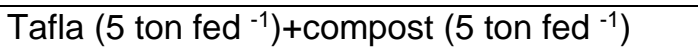 & 3.28 & 0.52 & 0.82 \\
\hline Tafla $\left(7.5\right.$ ton fed $\left.^{-1}\right)+$ compost $\left(7.5\right.$ ton fed $\left.^{-1}\right)$ & 3.37 & 0.58 & 0.86 \\
\hline Mean & 3.27 & 0.52 & 0.81 \\
\hline LSD $0.05 \%$ & 0.07 & 0.03 & 0.04 \\
\hline
\end{tabular}




\section{CONCLUSION}

Sandy soil has poor properties, i.e., low specific surface area, low water retention, low organic matter content, low fertility and high infiltration rate. These poor physical properties cause insufficient water use, especially in arid and semiarid regions. These adverse factors can be solved by several means; such as addition of natural (tafla) and organic (compost) amendments to improve poor soils. The compost can be a very good organic amendment in agriculture as well as for reclamation of sandy soils. Also, compost and tafla application was improved soil physical and chemical properties and sesame yield. The highest rate of 7.5 ton compost fed $^{-1}$ combined with 7.5 ton tafla fed $^{-1}$ application produced the best improvement of soil physical and chemical properties as well as sesame yield and its component.

\section{REFERENCES}

Abd El-Hady, M. and Ebtisam I. Eldardiry (2012). Sustainable reclamation of newly reclaimed sandy soil through local marine deposits application: IImprovement of hydrophysical characteristics. Journal of Applied Sciences Research, 8(4): 2350-2355.

Abd El-Hady, M. and Ebtisam I. Eldardiry (2012). Sustainable reclamation of newly and natural zeolite on sandy soil properties and productivity of some crops. Top Class Jour. of Agric. Res., 1: 22-28.

Abd El-Rheem, Kh.M., M.G.T. Zoghdan and Hayam A.A. Mahdy (2016). Effect of natural amendments as combined with different NPK fertilization combinations on nutrients content of wheat plant and sandy soil properties. Sci. Agri., 13 (3): 137-142.

Abdel Hady, M. (2005). Relations between some soil properties and soil moisture constants using path analysis. Egypt. J. Appl. Sci., 20 (5) :404 - 411.
Abdel-Nasser, G. and A.H.A. Hussein (2001). Effect of different manure sources on some soil properties and sunflower plant growth. 1. Soil physical and chemical properties. Alex. J. Agric. Res., 46: 227-251.

Abdel-Nasser, G., A.M. Al-Omran, A.M. Falatah, A.S. Sheta and A.R. Al-Harbi (2007). Impact of natural conditioners on water retention, infiltration and evaporation characteristics of sandy soil. Journal of Applied Sciences, 7: 16991708.

Abou Gabal, A., M.F. Abdel Sabour, F.A. Mohamad and M.A. Ragab (1989). Feasibility of sandy soil reclamation using local tafla as soil conditioner. Annals of Agricultural Science Cairo 34(2): 10031011.

Adriansen, H.K. (2009). Land reclamation in Egypt: a study of life in the new lands. Geoforum 40: 664-674

Ahmed, Hoda M. R. M., Enshrah I. M. ElMaaz and Kh. A. Shaban (2015). effect of compost and bentonite on sandy soil properties and productivity of peanut Egypt . J. of Appl. Sci., 30 (7): 335-354 .

Aiad, Nahed, A. M. E. (2010). Application of organic wastes for sustainable agriculture. Ph.D. Thesis, Fac of Agric., Minufiya Univ., Egypt.

Akbar, F., M. A. Rabbani, M. S. Masood, Z. Shinwari and K. Genetic (2011). Diversity of sesame (Sesame indicum L) germplasm from pakistan u sing RAPD markers, Pakistan Journal of Botany, 43: 4, $2153-2160$.

Akbari, K. N., G.S. Sutaria, V.D. Vora, D.S. Hirpara and D. R. Padmani (2010). Response of oilseed crops to enriched and vermicompost on Vertic ustochrept under rain fed conditions. An Asian Journal of Soil Science, 5 (1): 172-174.

Al-Omran, A.M., A.M. Falatah, A.S. Sheta and A.R. Al-Harbi (2004). Clay deposits for water management of sandy soils. Arid Land Res. Manage., 18: 171-184. 
Antoun, L.W., M.Z. Sahar and H.R. Hanaa (2010). Influence of compost, N-mineral and humic acid on yield and chemical composition of wheat plants. J. Soil Sci. and Agric. Engi. Mansoura Univ., 1(11): 1131-1143.

Black, C. A., D. D. Evans, L. E. Ensminger, J. L. White and F. E. Clark (1965). Methods of soil analysis Am. Soc of Agronomy. Agronomy Series No.9, Madison.Wisconsin,USA.

Chapman, H.D. and P.F. Pratt (1961). Methods of Analysis for Soils, Plants and Water. Agric. Publ. Univ., of California, Reverside.

Cottenie, A., M. Verloo, L. Kiekens, G. Velghe and R. Cameriynck (1982). "Chemical Analysis of Plant and Soil." Laboratory of Analytical and Agrochemistry, State Univ., Ghent, Belgium.

Croker, J., R. Poss, C. Hartmann and S. Bhuthorndharaj (2004). Effects of recycled bentonite addition on soil properties, plant growth and nutrient uptake in a tropical sandy soil. Plant and Soil 267: 155-163.

Curtis, M.J. and V.P. Claassen (2009). Regenerating topsoil functionality in four drastically disturbed soil types by compost incorporation. restore. J. Ecol. Res., 17: 24-32.

Eldardiry, Ebtisam I. and M. Abd El-Hady (2015). Effect of different soil conditioners application on some soil characteristics and plant growth I-Soil moisture distribution, barley yield and water use efficiency Global Advanced Research Journal of Agricultural Science. 4(7): 361-367.

El- Diwani, G., Sh.El-Rafei, S. Hawash and A. Kh. Ashraf (2012). Recovery of phorbol from oil of an Egyptian Jatropha. Asian J. of Plant Sci., 11 (3): 117- 123.

El- Eter, Wafaa M.T., E.M. Aly and T. A. Eid (2016). Effect of Irrigation Regime and Natural Soil Conditioner on Crop Productivity in Sandy Soil. Egypt. J. Soil. Sci. 56(2): 327-350.
El-Kholy, H.E.M., T.A. Abou El-Defan and M.M.M. El-Ghanam (2000). Influence of some natural soil conditioners on wheat grown on sandy soils. J. Agric. Sci. Mansoura Univ., 25: 5953-5971.

El-Maaz, Enshrah I.M., H. M. R. M. Ahmed and Kh. A. Shaban (2014). Soil chemical properties and wheat productivity as affected by organic, bio-fertilization and cultivation methods in saline soil. Minufiya, J. Agric. Res., 39 (6): 19551968.

El-Maghraby, T. A., M; A.A. Abdel-Salam and M. Abdel-Warth (2011). Effect of compost on maize (Zea mays) yield and some clay soil physical properties under deficit irrigation. J. Soil Sci. and Agric Eng., Mansoura Univ.2:611-622.

Emmanuel, A., C. Wim and R. Fatemeh (2012). Compost amendment of sandy soil affects soil properties and greenhouse tomato productivity. J. Compost Sci. \& Utilization., 20 (4): 215221.

Ferguson, J. (2015). Soil AmendmentsBentonite. www.natures way resources.com.

Gee, G. W. and J. W. Bauder (1986). Partial Size Analysis in Methods of Soil Analysis. Klute, Ed., Part 1, Agron, 9(15): 383-409, Am. Soc. Agron. Madison, Wisconsin, U.S.A.

Hartsock, N. J., T.G. Mueller, G. W. Thomas, R.I. Barnhisel, K. L. Wells and S. A. Shearer (2000). Soil Electrical Conductivity Variability. In.P. C. Robert et al. (ed) Porc. $5^{\text {th }}$ International Conference on Precision Agric. ASA. Misc. Publ., ASA,CSSA and SSSA, Medison, WI. USA.

Hassan, A. Z. A. and A. M. Mahmoud (2013). The combined effect of bentonite and natural zeolite on sandy soil properties and productivity of some crops. Top Class Journal of Agric., 1: 2228.

Kanu, P. J. (2011). Biochemical analysis of black and white sesame seeds from 
china, American journal of Biochemistry and Molecular Biology 1(2) $145-157$.

McNeill, J. D. (1980). Electrical conductivity of soils and Rocks. Tech. Note TN-5 Geonics Limited.Unit 8 Mississauga, Ontario Canada L5T IC6.

Mustafa, S. T. (2009). Effect of clay treatment on the productivity of sandy soil for wheat cultivation.M.Sc.Thesis Fac of Agric. Bang Unvi.

Nadeem, A., S. Kashani, N. Ahmed, M. Buriro, Z. Saeed, F. Mohammad and S. Ahmed (2015). Growth and yield of sesame (Sesamum indicum L.) under the influence of planting geometry and irrigation regimes. Amer. Plant Sci., 6: 980-986.

Noble, A.D., S. Ruaysoongnern, S. Berthelsen, Penning, de Vries, F.W.T. and M. Giordano (2005). Enhancing the agronomic productivity of degraded soils through clay-based interventions. The International Jour. of Agric. Sustainability 3: 102-113.

Ogbonna, P. E. and Y. G. Umar - Shaaba (2011). Yield responses of sesame (Sesamium indicum L) to rates of poultry manure application and time of planting in a derived savannah ecology of south eastern Nigeria African Journal of Biotechnology, 10(66): 14881 -14887.

Omran, A.M., A.M. Falatah and A.R. AlHarbi (2002). The use of natural deposits as an alternative for polymers on water management in arid calcareous sandy soils of Saudi Arabia. 17th World Congress of Soil Science, 14-21 August, Thailand.

Page, A.L., R. H. Miller and D. R. Keeny (1982). Methods of Soil Analysis. Part 2Chemical and Microbiological Properties
Second Edition Ajner. Soc. of Agron. Madison, Wisconsin, USA. 5371.

Richards, L. A. (1954). Diagnosis and Improvement of Saline and Alkali Soils U.S. Dept. Agric. Hand Book. No 60, U.S.Covt. Print. Office.

Shaban, Kh. A., M.G. Abd El-Kader and Z.M. Khalil (2012). Effect of soil amendments on soil fertility and sesame crop productivity under newly reclaimed soil conditions. J. of Appli. Sci. Res., 8 (3): 1568- 1575.

Snedecor, G. W. and W. G. Cochran (1980). Statistical Methods. $7^{\text {th }}$ Edition. Iowa State Univ. Press. Amer., IA., USA.

Stakman, W. P and G. G. Vanderhast (1962). The use of the pressure membrane apparatus to determine soil moisture constants at P. F 3.0 to 4.2 inclusive. Institute for Land and Water Management Res. Note No 139.

Suphasit, S., W. Richard and L. Viriya (2010). Effect of clay amendments on nitrogen leaching and forms in a sandy soil. 19 ${ }^{\text {th }}$ World Congress of Soil Solution for a Changing Word 1-6 August. Brisbane, Australia.

Toan, D. P., T.N.A. Thuy-Duong, S. Carlsson and T.M. Bui (2010). Morphological evaluation of sesame (Sesamum indicum L.) varieties from different origins Australian J. of Crop Sci., 4: 498-504.

Usman, A., Y. Kuzyakov and K. Stahr (2005). Effect of clay minerals on immobilization of heavy metals and microbial activity in a sewage sludge contaminated soil. Journal of Soils and Sediments. 5 (4): 245-252.

Wahab, M. A., G.W. Ageeb and F. Labib (2010). The agricultural investments of some Shale deposits in Egypt. Nature and Science, 75-81. 
Nahed A. M. E. Aiad, et al.,

تأثير المحسنات الطبيعية والعضوية على خواص الأرض الرملية و إنتاجية السمسم

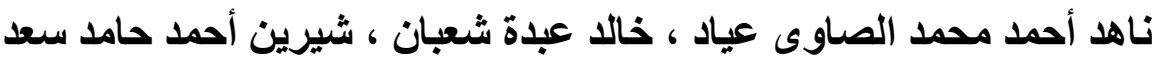

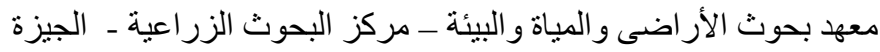

أجريت تجربتان حقليتان في موسمي الصيف 2015 و2016 في محطة البحوث الزر العية بالإسماعيلية وذلك لدر اسة تأثير

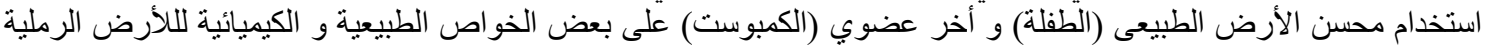

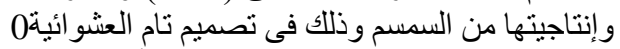
وكانت المعاملات تحت الدر اسة كالأنى :1 - -

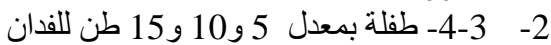

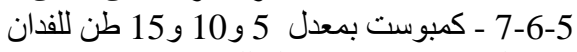

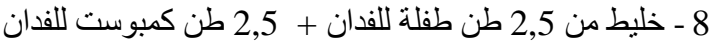

9 - خليط من5 طن طفلة للفدان + 5 طن طن كمبوست للفدان

10 - خليط من 5, 7 طن طفلة للفدان +

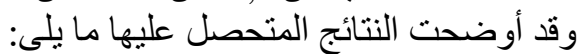

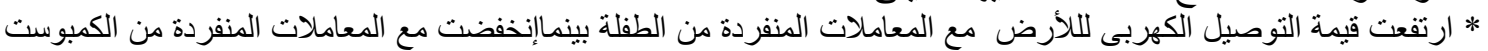

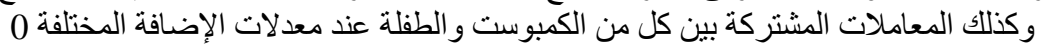

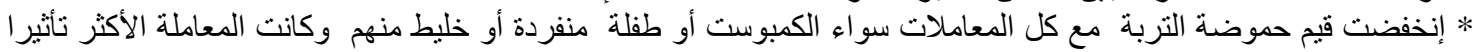

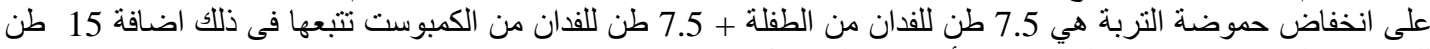

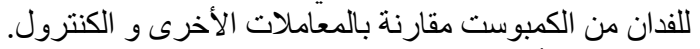

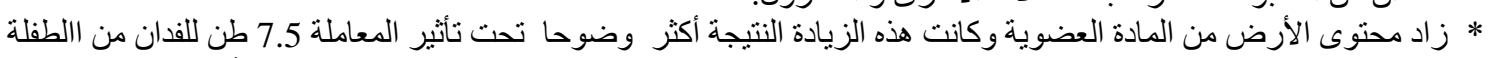

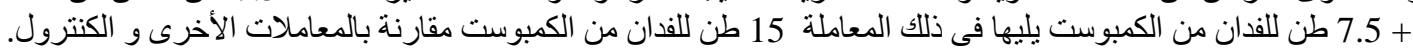

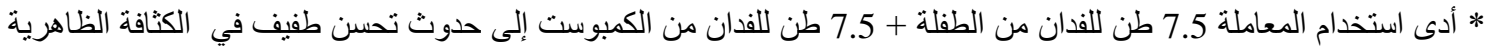

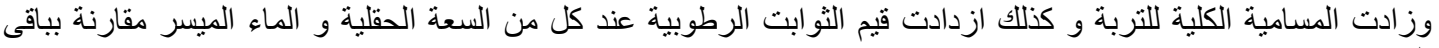

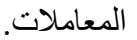

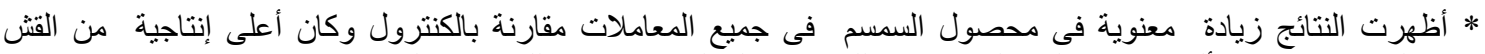

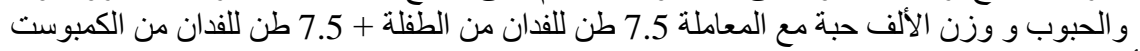

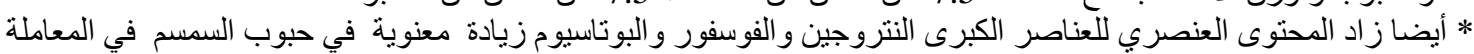

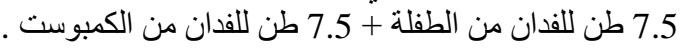

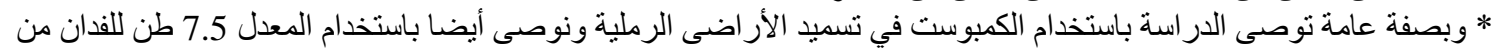

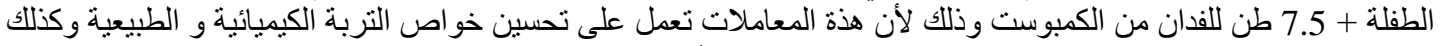

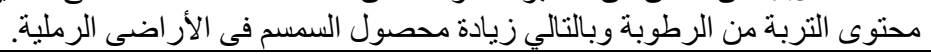

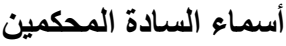

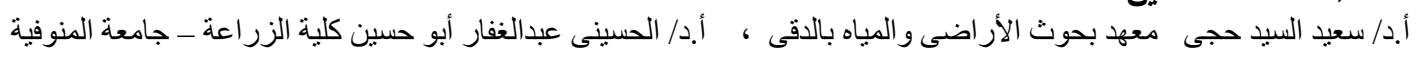

